\title{
MENINGKATKAN HASIL BELAJAR IPA FISIKA MELALUI PEMBELAJARAN INKUIRI TERBIMBING SISWA KELAS IX 5 SMP NEGERI 17 PEKANBARU
}

\author{
T. Etty Betriza \\ SMP Negeri 17 Pekanbaru \\ e-mail: ettybetriza@gmail.com
}

\begin{abstract}
Abstrak
Penelitian ini bertujuan untuk meningkatkan hasil belajar siswa melalui penerapan model pembelajaran inkuiri terbimbing pada materi listrik dinamis di kelas IX 5 SMP Negeri 17 Pekanbaru. Berdasarkan permasalahan siswa di kelas IX 5 dalam pembelajaran IPA Fisika yaitu: siswa menganggap fisika sulit dan hasil belajar sebahagian siswa masih di bawah kriteria ketuntasan minimal, maka perlu diterapkan model pembelajaran inkuiri terbimbing, yaitu salah satu model yang dapat meningkatkan hasil belajar siswa. Penelitian ini merupakan penelitian tindakan kelas dengan tiga siklus pada materi listrik dinamis. Subjek penelitian adalah siswa kelas IX 5 SMP Negeri 10 yang berjumlah 42 orang. Instrumen penelitian yaitu tes hasil belajar (postest) dan lembar observasi. Teknik pengumpulan data menggunakan teknik tes hasil belajar yang diberikan setelah satu siklus dilaksanakan sesuai dengan materi yang dibahas. Hasil belajar siswa dikumpulkan dan dianalisis secara deskriptif untuk memberikan gambaran tentang peningkatan hasil belajar siswa. Hasil kajian diperoleh peningkatan hasil belajar dari sikus I hingga siklus III yaitu pada siklus I siswa yang tuntas $69.05 \%$ dengan nilai rerata 80.6 , pada siklus II siswa yang tuntas $85.71 \%$ dengan nilai rerata 82.5 dan pada siklus III siswa yang tuntas $95.24 \%$ dengan nilai rerata 83,3 . Dengan demikian penerapan pembelajaran inkuiri terbimbing dapat meningkatkan hasil belajar ipa fisika siswa kelas IX 5 smp negeri 17 Pekanbaru pada materi listrik dinamis.
\end{abstract}

Kata kunci : hasil belajar, inkuiri terbimbing, listrik dinamis

\begin{abstract}
This research aimed to improve student learning outcomes through the implementation of guided inquiry learning model on electrical dynamic materials in class IX 5 SMP Negeri 17 Pekanbaru. Based on the problems of class IX 5 students in physics science learning: students consider that physics is difficult and the learning outcomes of some students are still below the minimum mastery criteria, it is necessary to apply inquiry learning model, that is one model that can improve student learning outcomes. This research is a classroom action research with three cycles on dynamic electrical materials. The subjects of the research were the students of class IX 5 SMPN 10 which amounted to 42 student. The research instrument is a test of learning outcomes (postest) and observation sheet. The data collection technique uses the learning outcomes test technique, which is given after one cycle is implemented in accordance with the material discussed. Student learning outcomes are collected and analyzed descriptively to provide an overview of the improvement of student learning outcomes. The result of the research is the improvement of learning outcomes from cycle I to cycle III that is in the first cycle of students who complete $69.05 \%$ with the average value of 80.6 , in the second cycle of students who complete $85.71 \%$ with the average value of 82.5 and in the third cycle of students who complete $95.24 \%$ with the average value 83.3 . Thus the implementation of guided inquiry learning can improve learning outcomes physics students class IX 5 SMP 17 Pekanbaru on dynamic electrical materials.
\end{abstract}

Keywords : learning outcomes, guided inquiry, electrodinamic 


\section{Pendahuluan}

Pendidikan adalah pandangan hidup yang mendasari seluruh aktivitas pendidikan (Nata, 2005). Menurut Zuhairini, et al. (2008), pendidikan sering diartikan sebagai suatu usaha manusia untuk membimbing anak yang belum dewasa ke tingkat kedewasaan, dalam arti sadar dan mampu memikul tanggung jawab atas segala perbuatannya dan dapat berdiri di atas kaki sendiri. Selanjutnya Hasbullah (2009) mengatakan bahwa pendidikan adalah usaha sadar dan terencana untuk mewujudkan suasana belajar dan proses pembelajaran agar peserta didik secara aktif mengembangkan potensi dirinya untuk memiliki kekuatan spiritual keagamaan, pengendalian diri, kepribadian, kecerdasan akhlak mulia, serta keterampilan yang diperlukan dirinya, masyarakat, bangsa dan negara.

Salah satu komponen yang berperan penting adalah guru. Peran guru sebagai sumber belajar merupakan peran yang sangat penting, peran sebagai sumber belajar berkaitan erat dengan penguasaan materi pelajaran. Kita bisa menilai baik atau tidaknya seorang guru hanya dari penguasaan materi pelajaran (Sanjaya, 2010).

Mata pelajaran IPA sebagai proses pembelajaran yang menekankan pada pemberian pengalaman langsung untuk mengembangkan kompetensi agar menjelajahi dan memahami alam sekitar secara alamiah. Pembelajaran IPA fisika diarahkan untuk inkuiri dan berbuat, sehingga dapat membantu peserta didik untuk memperoleh pemahaman yang lebih mendalam tentang alam sekitar. Oleh karena itu, pembelajaran IPA fisika menekankan pada pemberian pengalaman belajar secara langsung melalui penggunaan dan pengembangan keterampilan proses dan sikap ilmiah (Elfis, 2010).

Proses belajar dan mengajar yang baik akan meningkatkan hasil belajar siswa. Menurut Sardiman (2007), dari proses belajar mengajar akan diperoleh suatu hasil, yang pada umumnya disebut hasil pengajaran, atau dengan istilah tujuan pembelajaran atau hasil belajar. Tetapi agar memperoleh hasil yang optimal, proses belajar mengajar harus dilakukan dengan sadar dan sengaja serta terorganisasi secara baik.
Berdasarkan pengalaman penulis selama mengajar di SMP Negeri 17 Pekanbaru diperoleh informasi yaitu: (a) siswa cenderung berbicara ketika guru menerangkan, (b) siswa cenderung menganggap fisika sulit dan rumit, (c) siswa kurang termotivasi dalam belajar, (d) siswa sulit bekerja sama dalam kelompok dan cenderung bersifat individu, (e) kurangnya aktifitas tanya jawab siswa, (f) hasil belajar siswa yang di bawah KKM (Kriteria Ketuntasan Minimal) yaitu 30\% dengan KKM 82.

Jelas terlihat dari uraian sebelumnya bahwa terdapat permasalahan yang dihadapi siswa dalam proses belajar mengajar, maka guru sebagai fasilitator dan motivator harus mengoptimalkan proses belajar siswa dan memilih suatu model pembelajaran yang dapat meningkatkan hasil belajar siswa. Untuk menciptakan kondisi pembelajaran yang dinamis maka peneliti menggunakan pembelajaran inkuiri terbimbing. Dalam model pembelajaran inkuiri terbimbing, siswa sebagai subjek dan objek dalam belajar yang mempunyai kemampuan dasar untuk berkembang secara optimal sesuai dengan kemampuan yang dimilikinya. Kemudian siswa lebih banyak belajar sendiri, mengembangkan kekreatifan dalam pemecahan masalah.

Menurut Herdian (2011), pembelajaran inkuiri terbimbing ini digunakan bagi siswa yang kurang berpengalaman belajar dengan inkuiri. Dengan pembelajaran inkuiri terbimbing (guided inquiry) ini siswa belajar lebih berorientasi pada bimbingan dan petunjuk dari guru hingga siswa dapat memahami konsep-konsep pelajaran. Pada pendekatan ini siswa akan dihadapkan pada tugas-tugas yang relevan untuk diselesaikan baik melalui diskusi kelompok maupun secara individual agar mampu menyelesaikan masalah dan menarik suatu kesimpulan secara mandiri.

Menurut Nasution dalam Uno dan Mohamad (2011), belajar adalah aktivitas yang menghasilkan perubahan dari diri individu yang belajar, baik aktual maupun potensial. Perubahan itu pada dasarnya berupa didapatkannnya kemungkinan baru, yang berlaku dalam waktu yang relatif lama. Belajar adalah suatu proses yang memungkinkan timbulnya atau berubahnya suatu tingkah laku sebagai hasil dari terbentuknya respon utama, 
dengan syarat bahwa perubahan atau munculnya tingkah laku baru itu disebabkan oleh adanya kematangan atau adanya perubahan sementara karena sesuatu hal.

Winkel dalam Anwar \& Harmi (2011), mengatakan bahwa belajar adalah aktivitas mental atau psikis yang berlangsung dalam interaksi aktif dengan lingkungan yang menghasilkan perubahan tingkat pengetahuan, pemahaman, keterampilan, dan nilai sikap. Jadi secara umum belajar merupakan kegiatan aktif mahasiswa dalam membangun makna atau pemahaman. Menurut Hendy (2011), salah satu kompetensi guru yang menunjang keberhasilan proses belajar mengajar adalah memahami berbagai model pembelajaran dan mampu menggunakannya dengan baik. Peran utama guru adalah memberikan pengalaman dan memperkaya pengetahuan siswa dengan mengeksplorasi lingkungan dengan proses pembelajaran yang sesuai.

Belajar merupakan tindakan dan perilaku siswa yang kompleks. Sebagai tindakan, maka belajar hanya dialami oleh siswa sendiri (Dimyati \& Mudjiono, 2009). Bila terjadi proses belajar, maka bersama itu pula terjadi proses mengajar (Sardiman, 2007). Selanjutnya Sardiman (2007) mengatakan bahwa dari proses belajar mengajar ini akan diperoleh hasil, yang pada umumnya disebut hasil pengajaran, atau dengan istilah tujuan pembelajaran atau hasil belajar. Tetapi agar memperoleh hasil yang optimal, proses belajar mengajar harus dilakukan dengan sadar dan sengaja serta terorganisasi secara baik.

Hasil belajar adalah kemampuan siswa dalam memenuhi suatu tahapan pencapaian pengalaman belajar dalam suatu kompetensi dasar. Hasil belajar dalam silabus berfungsi sebagai petunjuk tentang perubahan perilaku yang akan dicapai oleh siswa sehubungan dengan kegiatan belajar yang dilakukan, sesuai dengan kompetensi dasar dan materi standar yang dikaji. Hasil belajar bisa berbentuk pengetahuan, keterampilan, maupun sikap (Kunandar, 2011).

Inkuiri merupakan pengajaran yang berpusat pada siswa. Dalam pengajaran ini siswa jadi aktif belajar. Tujuan model inkuiri adalah mengembangkan keterampilan intelektual, berfikir kritis, dan mampu memecahkan masalah secara ilmiah (Dimyati dan Mudjiono, 2009). Inkuiri merupakan bagian inti dari kegiatan pembelajaran berbasis kontekstual. Pengetahuan dan keterampilan yang diperoleh siswa diaharapkan bukan hasil mengingat seperangkat fakta-fakta, tetapi hasil dari menemukan sendiri. Guru harus selalu merancang kegiatan yang merujuk pada kegiatan menemukan apapun materi yang diajarkannya (Trianto, 2007).

Menurut Herdian (2010), model inkuiri terbimbing ini digunakan bagi siswa yang kurang berpengalaman belajar dengan model inkuiri. Dengan model inkuiri terbimbing (guided inquiry) ini siswa belajar lebih berorientasi pada bimbingan dan petunjuk dari guru hingga siswa dapat memahami konsepkonsep pelajaran. Pada model inkuiri terbimbing (guided inquiry) ini siswa akan dihadapkan pada tugas-tugas yang relevan untuk diselesaikan baik melalui diskusi kelompok maupun secara individual agar mampu menyelesaikan masalah dan menarik suatu kesimpulan secara mandiri.

Adapun langkah-langkah pembelajaran inkuiri yang harus dilakukan oleh guru menurut Tabel 1.

Tabel 1. Langkah-langkah Pembelajaran Inkuiri

\begin{tabular}{|c|c|}
\hline Fase & Guru \\
\hline $\begin{array}{l}\text { Menyajikan } \\
\text { pertanyaan atau } \\
\text { masalah }\end{array}$ & $\begin{array}{l}\text { Guru membimbing siswa } \\
\text { mengidentifikasi masalah }\end{array}$ \\
\hline $\begin{array}{l}\text { Membuat } \\
\text { hipotesis }\end{array}$ & $\begin{array}{l}\text { Guru membimbing siswa } \\
\text { dalam menentukan hipotesis } \\
\text { yang relevan }\end{array}$ \\
\hline $\begin{array}{l}\text { Merancang } \\
\text { percobaan }\end{array}$ & $\begin{array}{l}\text { Guru memberikan kesempa- } \\
\text { tan kepada siswa untuk } \\
\text { menentukan langkah-lang- } \\
\text { kah yang sesuai dengan } \\
\text { hipotesis yang akan dilaku- } \\
\text { kan. Membimbing siswa } \\
\text { mengurutkan langkah-lang- } \\
\text { kah percobaan }\end{array}$ \\
\hline $\begin{array}{l}\text { Melakukan } \\
\text { percobaan untuk } \\
\text { memperoleh } \\
\text { informasi }\end{array}$ & $\begin{array}{l}\text { Guru membimbing siswa } \\
\text { mendapatkan informasi } \\
\text { melalui percobaan }\end{array}$ \\
\hline $\begin{array}{l}\text { Mengumpulkan } \\
\text { dan menganalisa } \\
\text { data }\end{array}$ & $\begin{array}{l}\text { Guru memberikan kesempa- } \\
\text { tan pada tiap kelompok } \\
\text { untuk menyampaikan hasil } \\
\text { observasi }\end{array}$ \\
\hline $\begin{array}{l}\text { Membuat } \\
\text { kesimpulan }\end{array}$ & $\begin{array}{l}\text { Guru membimbing siswa } \\
\text { dalam membuat kesimpulan }\end{array}$ \\
\hline
\end{tabular}

Sumber: Trianto, 2009. 
Tujuan penelitian ini yaitu untuk mengetahui peningkatan hasil belajar fisika siswa kelas IX 5 SMP Negeri 17 Pekanbaru setelah penerapan pembelajaran inkuiri terbimbing (guided inquiry). Oleh karena itu, penelitian ini menarik untuk dilaksanakan dengan judul penerapan pembelajaran inkuiri terbimbing (guided inquiry) terhadap hasil belajar fisika siswa kelas IX 5 SMP Negeri 17 Pekanbaru.

\section{Bahan dan Metode}

Penelitian ini telah dilaksanakan pada bulan Agustus sampai dengan September 2016 di kelas IX 5 SMP Negeri 17 Pekanbaru Tahun Pelajaran 2016/2017. Subjek penelitian adalah siswa kelas IX 5 yang berjumlah 42 orang siswa.

Penelitian ini merupakan penelitian tindakan kelas dengan tiga siklus (setiap siklus dua kali pertemuan), yang menerapkan pembelajaran inkuiri terbimbing untuk meningkatkan hasil belajar siswa kelas IX 5 SMP Negeri 17 Pekanbaru, pada materi listrik dinamis. Instrumen penelitian yang digunakan yaitu perangkat pembelajaran (RPP dan LKS) serta instrumen tes hasil belajar. Teknik pengumpulan data menggunakan data tes hasil belajar siswa yang diberikan setelah satu siklus dilaksanakan sesuai dengan materi yang dibahas menurut Tabel 2.

Tabel 2. Materi Listrik Dinamis dalam Pelaksanaan Penelitian PTK

\begin{tabular}{clc}
\hline No. & \multicolumn{1}{c}{ Sub Pokok Bahasan } & Siklus \\
\hline 1 & Arus listrik & I \\
2 & Rangkaian listrik & \\
3 & Karakteristik rangkaian listrik & II \\
4 & Sumber arus listrik & \\
5 & Sumber-sumber energi listrik & III \\
6 & Transmisi energi listrik & \\
\hline
\end{tabular}

Tahapan penelitian PTK yang dilaksanakan untuk setiap siklus yaitu mulai dari perencanaan, pelaksanaan tindakan, pengamatan, sampai kepada tahap refleksi. Hasil belajar siswa ini dikumpulkan dan dianalisis secara deskriptif untuk memberikan gambaran tentang peningkatan hasil belajar siswa melalui test hasil belajar yang diberikan setiap siklus.
Kriteria penarikan kesimpulan yaitu dinyatakan terjadi peningkatan hasil belajar siswa apabila terjadi peningkatan nilai hasil belajar siswa dari siklus satu ke siklus dua dan dari siklus dua ke siklus tiga.

\section{Hasil dan Pembahasan}

Untuk mendapatkan hasil belajar siswa setelah siklus I dilaksanakan ulangan harian berupa test tertulis hasil belajar yang diikuti oleh 42 siswa. Hasil pelaksanaan PTK tiga siklus diperoleh data hasil belajarnya menurut Tabel 3 sampai Tabel 5.

Hasil belajar siklus I untuk materi arus listrik dan rangkaian listrik diperoleh hasil menurut Tabel 3 dimana siswa yang tuntas 29 orang $(69,05 \%)$ dan yang tidak tuntas 13 orang (30,95\%). Refleksi pada siklus I menunjukkan bahwa masih lebih dari 10 orang siswa belum tuntas hasil belajarnya. Berdasarkan hasil observasi diketahui penyebabnya, terdapat beberapa siswa belum mampu mengikuti dengan baik model pembelajaran inkuiri terbimbing yang digunakan. Selain itu materi arus listrik dan rangkaian listrik juga menjadi kendala bagi sebagian siswa, karena memerlukan analisis rangkaian. Untuk itu, maka pada siklus berikutnya dilakukan pembimbingan lebih intensif dalam proses pembelajaran disertai latihan yang cukup.

Tabel 3. Rekap Nilai Hasil Post Test Siswa Siklus 1

\begin{tabular}{clcc}
\hline No & \multicolumn{1}{c}{ Uraian } & Jumlah & $\begin{array}{c}\text { Persentase } \\
(\mathbf{\%})\end{array}$ \\
\hline 1 & Siswa tuntas & 29 & 69,05 \\
2 & $\begin{array}{l}\text { Siswa tidak } \\
\text { tuntas }\end{array}$ & 13 & 30,95 \\
3 & Jumlah nilai & 3.385 & \\
4 & Nilai rata-rata & 80,6 & \\
\hline
\end{tabular}

Hasil pelaksanaan siklus II setelah diberikan ulangan harian, diperoleh peningkatan hasil belajar siswa yang tuntas menjadi $85.71 \%$ dan yang belum tuntas berkurang menjadi $14.29 \%$ sebagaimana terlihat pada Tabel 4. Masih terdapatnya 6 orang siswa yang belum tuntas, maka hasil refleksi siklus II diketahui masih perlunya 
pembimbingan lebih baik teutama pada siswa yang masih mengalami kesulitan dalam mengikuti model pembelajaran yang diterapkan, disamping materinya juga terdapat analisis rangkaian. Walaupun perolehan nilai pada siklus II sudah mengalami peningkatan, namun beberapa siswa (6 orang) belum mencapai nilai KKM yang sudah ditetapkan, Oleh karena itu, pengkaji melanjutkan PTK ini pada siklus III.

Tabel 4. Rekap nilai hasil post test siswa siklus II

\begin{tabular}{clcc}
\hline No & \multicolumn{1}{c}{ Uraian } & Jumlah & $\begin{array}{c}\text { Persentase } \\
(\mathbf{\%})\end{array}$ \\
\hline 1 & Siswa tuntas & 36 & 85.71 \\
2 & $\begin{array}{l}\text { Siswa tidak } \\
\text { tuntas }\end{array}$ & 6 & 14.29 \\
3 & Jumlah nilai & 3.464 & \\
4 & Nilai rata-rata & 82.5 & \\
\hline
\end{tabular}

Refleksi berdasarkan hasil analisis siklus III, diperoleh melalui observasi dan hasil ulangan siklus III yang diperlihatkan pada Tabel 5. Hasil belajar siklus III menunjukkan peningkatan dibanding siklus I dan siklus II, dimana terdapat $95.24 \%$ beserta dinyatakan tuntas hasil belajarnya dan hanya $4.76 \%$ yang belum tuntas. Dengan demikian penerapan model inkuiri terbimbing dapat meningkatkan hasil belajar siswa pada materi listrik dinamis di kelas IX 5 SMP Negeri 17 Pekanbaru. Terdapatnya sebagian kecil siswa yang belum tuntas, hal ini berarti bahwa penerapan model inkuiri training perlu lebih dioptimalkan lagi dari aspek perangkat pembelajaran, instrumen penilaian, dan sistem pengoganisasian dalam proses pembelajaran.

Tabel 5. Rekap Nilai Hasil Post Test Siswa Siklus III

\begin{tabular}{clcr}
\hline No & Uraian & Jumlah & $\begin{array}{c}\text { Persentase } \\
\mathbf{( \% )}\end{array}$ \\
\hline 1 & Siswa tuntas & 40 & 95,24 \\
2 & $\begin{array}{l}\text { Siswa tidak } \\
\text { tuntas }\end{array}$ & 2 & 4.76 \\
3 & Jumlah nilai & 3.541 & \\
4 & Nilai rata-rata & 83,3 & \\
\hline
\end{tabular}

Secara keseluruhan hasil belajar siswa dapat dilihat peningkatannya menurut grafik pada Gambar 1, yang memperlihatkan peningkatan hasil belajar siswa dengan standar ketuntasan mengacu kepada KKM dari siklus I siswa yang tuntas $69.05 \%$ dengan nilai rerata 80.6 , siklus II siswa yang tuntas menjadi $85.71 \%$ dengan nilai rerata 82.5 , dan pada siklus ke III jumlah siswa yang tuntas meningkat lagi menjadi $95.24 \%$ dengan nilai rerata 83.3. Adapun persentase siswa yang tidak tuntas dari siklus I hingga siklus III semakin berkurang. Berdasarkan hasil penelitian tindakan kelas ini, menunjukkan bahwa model pembelajaran inkuiri terbimbing mampu meningkatkan hasil belajar siswa pada mata pelajaran fisika pada materi listrik dinamis. Peningkatan hasil belajar dilihat dari hasil ulangan harian pada setiap siklus yang diberikan setelah proses pembelajaran berlangsung dalam satu siklus.

Hasil penelitian ini sejalan dengan penelitian yang terkait yaitu hasil penelitian Daniah (2015) yang berhasil memperbaiki dan meningkatkan sikap ilmiah serta hasil belajar mata kuliah IPA terhadap mahasiswa jurusan PGMI UIN AR-RANIRY melalui penggunaan model pembelajaran inkuiri terbimbing. Hasil serupa juga sesuai hasil penelitian Sari (2011) yang berhasil meningkatkan hasil belajar IPA fisika siswa Kelas VIIa SMPN I Sungai Lala Kabupaten Indragiri Hulu dengan menerapkan pembelajaran inkuiri terbimbing, serta dari kajian Andriani (2012) menggunakan inkuiri terbimbing dengan kategori efektif. Dengan demikian model pembelajaran inkuiri terbimbing sesuai digunakan bagi meningkatkan hasil belajar siswa SMP pada materi listrik dinamis atau materi yang relevan.

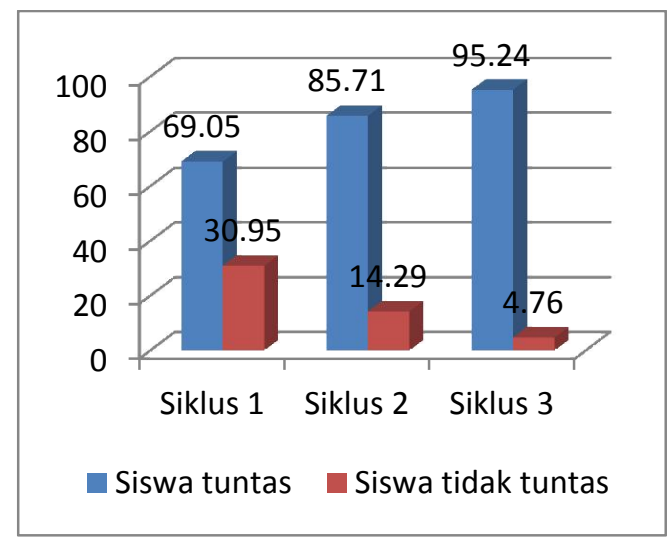

Gambar 1. Grafik hasil belajar siswa 


\section{Kesimpulan dan saran}

Berdasarkan hasil penelitian tindakan kelas ini diperoleh kesimpulan bahwa penerapan model inkuiri terbimbing dalam membelajarkan materi listrik dinamis di kelas IX 5 SMP Negeri 17 Pekanbaru tahun pelajaran 2016/2017, dapat meningkatkan hasil belajar siswa mulai dari siklus I ke siklus II sampai ke siklus III. Dengan demikian penerapan model inkuiri terbimbing dapat digunakan sebagai model pembelajaran inovatif untuk meningkatkan hasil belajar siswa.

Penerapan pembelajaran menggunakan model inkuiri terbimbing, hendaknya guru dituntut untuk lebih maksimal lagi dalam persiapan perangkat pembelajaran yang sesuai dengan model dan karakteristik siswa dan lebih memaksimalkan pengelolaan kelas, sehingga situasi kelas menjadi lebih baik. Selain itu penerapan model inkuri terbimbing juga dapat dilihat dari aspek lain seperti aktivitas atau motivasi belajar siswa.

\section{Daftar Pustaka}

Andriani, 2011. Efektifitas Penerapan Pembelajaran Inkuiri Terbimbing (Guided Inquiry) pada Mata Pelajaran Fisika SNIPS, Universitas Sriwijaya.

Anwar \& Harmi, 2011. Perencanaan Sistem Pembelajaran Kurikulum Tingkat Satuan Pendidikan (KTSP). Alfabeta, Bandung.

Arikunto, S., Suhardjono \& Supardi, 2008. Penelitian Tindakan Kelas. Bumi Aksara, Bandung.

Dimyati \& Mudjiono, 2009. Belajar dan Pembelajaran. Rineka Cipta, Jakarta.

Daniah, 2015. Penggunaan Model Pembelajaran Inkuiri Terbimbing Pada Mata Kuliah IPA Terhadap sikap Ilmiah dan Hasil Belajar Mahasiswa Jurusan PGMI UIN AR-RANIRY.

Elfis. 2010b. Bahan Ajar Cetak. Available at: http://elfisuir.blogspot.com.

Hasbullah, 2009. Dasar-Dasar Ilmu Pendidikan. PT Raja Grafindo Persada, Jakarta.
Herdian, 2011. Model Pembelajaran Inkuiri. http://hendy07.wordpress.com/2010/mo del-pembelajaran-inkuiri/ Diakses pada tanggal 30 Oktober 2017.

Kunandar, 2011. Guru Profesional Implementasi Kurikulum Tingkat Satuan Pendidikan (KTSP) dan Sukses dalam Sertifikasi Guru. PT Raja Grafindo Persada, Jakarta.

Nata, A., 2005. Filsafat Pendidikan Islam. Gaya Media Pratama, Jakarta.

Rusman, 2011. Model-model Pembelajaran Mengembangkan Profesionalisme Guru. PT Raja Grafindo Persada, Jakarta.

Sadiman, S, A., Rahardjo, R., dan Haryono, A., 2009. Media Pendidikan. PT Raja Grafindo Persada, Jakarta.

Sanjaya, W., 2010. Strategi Pembelajaran Berorientasi Standar Proses Pendidikan. Kencana, Jakarta.

Sardiman, 2007. Interaksi dan Motivasi Belajar Mengajar. PT Raja Grafindo Persada, Jakarta.

Sari, P. F., 2011. Pembelajaran Inkuiri Terbimbing untuk Meningkatkan Hasil Belajar Biologi Siswa Kelas VIIa SMPN I Sungai Lala Kabupaten Indragiri Hulu Tahun Ajaran 2010/2011. Skripsi Universitas Islam Riau. Program Studi Pendidikan Biologi, Pekanbaru.

Trianto, 2009. Mendesain Model Pembelajaran Inovatif Progresif. Kencana, Jakarta.

Uno, H. B., \& Mohamad. N., 2011. Belajar dengan Pendekatan Pembelajaran Aktif Inovatif Lingkungan Kreatif Efektif Menarik. Bumi Aksara, Jakarta.

Zubaidah, S., 2010. Pembelajaran Kolaboratif dan Group Investigation: Sebagai Salah Satu Teknik Pembelajaran Kolaboratif. Makalah yang disampaikan pada Seminar Nasional Pendidikan Biologi pada tanggal 12 Juni 2010 di Universitas Islam Riau, Pekanbaru.

Zuhairini, Kasiran. M., Ghotir. A., Tadjab \& Fadjar, M.A., 2008. Filsafat Pendidikan Islam. Bumi Aksara, Jakarta. 